\title{
Metabolomics analysis of the Lolium perenne-Neotyphodium lolii symbiosis: more than just alkaloids?
}

\author{
Susanne Rasmussen · Anthony J. Parsons • \\ Jonathan A. Newman
}

Received: 19 November 2008/ Accepted: 27 April 2009

(C) Springer Science+Business Media B.V. 2009

\begin{abstract}
Above ground plant parts of Lolium perenne often harbour endophytic Neotyphodium lolii fungi. These occur both naturally and commercially, as variant strains are introduced to modify the grass metabolic profile. They reside in the apoplastic spaces and rarely cause visible symptoms of infection. The vast majority of literature has focussed on the biosynthesis, accumulation, and ecological relevance of a limited number of alkaloids produced by $N$. lolii which have been shown to negatively affect insect pests and vertebrate herbivores. Much less is known about the effects of other metabolites in these interactions or the role of resource supply on metabolic profiles, nor critically on the metabolic consequences of differences in the amount (concentration) of endophyte present. Here, we provide a synthesis of some of our recently published studies on effects of resource supply (nitrogen, carbohydrates) on concentrations of endophytes and endophyte specific metabolites in the L. perenne-N. lolii association. We present results of both quantitative PCR and targeted metabolomics studies, using contrasting
\end{abstract}

S. Rasmussen $(\square) \cdot$ A. J. Parsons

AgResearch Grasslands, Tennent Drive, Palmerston North 4442, New Zealand

e-mail: Susanne.rasmussen@agresearch.co.nz

\section{J. A. Newman}

Department of Environmental Biology,

University of Guelph, Guelph N1G 2W1, Canada endophyte strains in two perennial ryegrass cultivars. We also present and discuss a hypothetical schematic representation of possible links between plant and fungal metabolic networks. A multiple regression analysis of numerical insect responses and metabolic profiles indicates that effects of endophyte infection on insect population sizes could be predicted by concentrations of a range of metabolites other than alkaloids and depended on insect species, fungal strain, and nitrogen supply.

Keywords Ryegrass - Carbohydrates .

Nitrogen $\cdot$ Herbivory $\cdot$ Metabolomics

\section{Introduction}

Temperate and tropical grasses are often infected with endophytic fungi belonging to the genus Clavicipitaceae (Leuchtmann 1993). The best studied symbiotic associations of this type are Neotyphodium lolii-Lolium perenne (ryegrass) and the $N$. coenophialum-Schedonorus arundinaceus (syn. L. arundinaceum, tall fescue), as these are of relevance to agricultural pasture-based animal production systems especially in Australia, New Zealand, and the USA (Christensen et al. 1993). In contrast to some plant mutualists (e.g. the well researched mycorrhizae) these endophytes do not extend outside the plant; they reside almost entirely in the apoplastic spaces 
(between plant cells) of above ground plant parts (Fig. 1a), although very small amounts of fungi can also be detected in root tips (Christensen et al. 2008). While some Epichlö̈spp. have sexual stages that can cause damage to plant seed heads (choke disease), their asexual Neotyphodium spp. descendants are asexual and rarely cause any visible symptoms of disease. Unlike many biotrophic fungal pathogens and mycorrhizae which invade plant cells and form specific intracellular structures (haustoria and arbuscules, respectively) and membrane interfaces for nutrient transport between host and fungus (Hall and Williams 2000; Hahn and Mendgen 2001 and references therein), the Neotyphodium/Epichloë endophytes do not invade cells and no specific membrane interfaces are known to be formed in this association. However, it has been shown that fungal hyphae are firmly attached to plant cells (Fig. 1; Christensen et al. 2008), and it is possible that nutrients are transported from plant to fungal cells at the site of attachment, although the prevalent hypothesis is that nutrients are taken up by the fungus from the apoplastic fluid in the intercellular space in which it resides (Hinton and Bacon 1985). Of importance to recognise here is that to the best of current understanding, this means that all resources required by the fungus must be obtained solely from the host plant.

Neotyphodium/Epichloë fungi synthesize a range of alkaloids, mainly the pyrrolopyrazine peramine, the indole-diterpene lolitrem B, the peptide alkaloid ergovaline, and, in the case of $N$. coenophialum, several lolines (Bush et al. 1997; Lane et al. 2000; Schardl et al. 2004). The alkaloids can confer resistance against a range of insects to the host plants and so improve plant productivity (Rowan et al. 1986; Fletcher and Easton 1997; Schardl 2001; Clay and Schardl 2002). However, some alkaloids (e.g. ergovaline and lolitrem B) have detrimental effects on grazing mammals, causing e.g. fescue toxicosis (Lyons et al. 1986; Strickland et al. 1996) and ryegrass 'staggers' (Gallagher et al. 1984) in cattle and sheep, resulting in production losses, and welfare concerns, for the meat and dairy industry. Recently, several new fungal strains lacking (or very low in) lolitrem B and ergovaline have been commercialised and are used to infect ryegrass (AR1, AR37) and tall fescue (AR542, known commercially as Max Q, and also as Max P). While AR1 produces peramine as the major alkaloid, AR37 does not produce any of the commonly known and extensively studied alkaloids, but synthesizes epoxy-janthitrems instead (Tapper and Lane 2004). Concentrations of alkaloids found in infected plant tissues have been reported to depend on a variety of factors like e.g. nutrient availability or host genotype. To date, it is not clear to what extent these differences in alkaloid concentrations depend on the metabolic activity of the fungus per se (e.g. as the result of changes in fungal gene expression or enzyme activities); or if low/high alkaloid levels are due in some circumstances to different and changeable concentrations of fungal tissue in the fungus/host association.

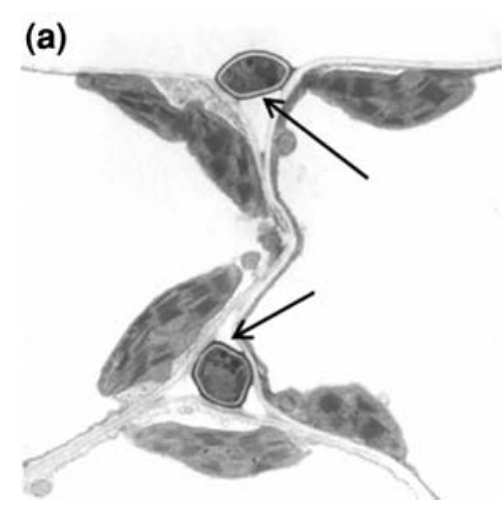

Fig. 1 Micrographs of Neotyphodium endophytic hyphae in planta. a Aniline-blue stained $N$. lolii hyphae (arrows) in ryegrass leaf sheath. a TEM micrograph showing $N$. lolii hyphae (arrows) in the intercellular spaces of a young ryegrass

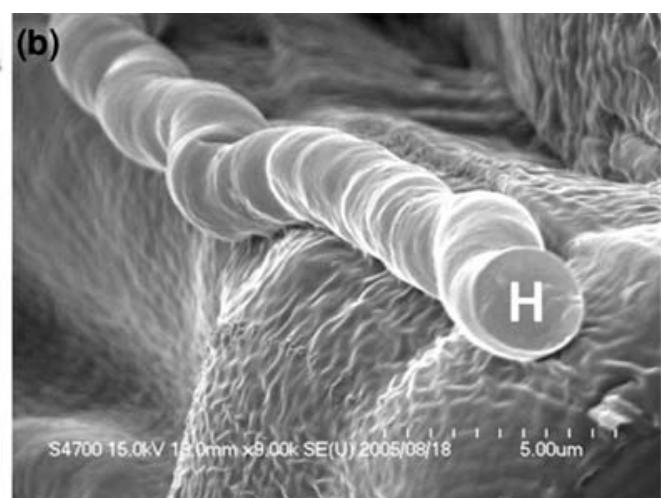

leaf blade. b Freeze-fracture SEM micrograph showing a hyphae $(\mathrm{H})$ of $N$. coenophialum in close contact with tall fescue leaf cells. Micrographs have been reproduced from Christensen et al. (2008) (Fig. 1) with permission from Elsevier 
Apart from negative effects of endophyte alkaloids on herbivores, it has also been shown that endophytes can have beneficial effects on other plant fitness parameters e.g. improving drought and mineral stress tolerance (Malinowski et al. 1998a; Amalric et al. 1999; Malinowski and Belesky 2000; Hesse et al. 2003, 2005), although the mechanisms responsible for these benefits remain largely unresolved. The host/fungal association has been viewed generally as mutualistic, though this concept has been challenged recently (Cheplick 2004; Saikkonen et al. 2004, 2007; Müller and Krauss 2005). The heterotrophic endophyte depends on substrates provided by the autotrophic host plant and a metabolic cost to the host has therefore been postulated (Cheplick 2007), though very few studies attempting to quantify these costs have been published so far. The balance of endophyte effects on plant performance has been shown to depend e.g. on resource supply (Cheplick et al. 1989; Malinowski et al. 1998b), and evidence of negative effects of high resource supply in the host, on endophyte abundance, would favour seeing the association as a mutualism-parasitism continuum.

Previous transcriptomics and metabolomics studies of the rhizospheric rhizobium-legume, and arbuscular mycorrhiza-plant, mutualistic associations have revealed that such endosymbionts can induce a wide range of changes in gene transcript and metabolite profiles and concentrations (Hohnjec et al. 2005; Schliemann et al. 2008). Recent metabolomics and transcriptomics studies on effects of parasitic fungal biotrophs in maize (Zea mays; Doehlemann et al. 2008) and Brassica rapa (Abdel-Farid et al. 2009) have also shown widespread reprogramming of host plants' metabolism. Here, we provide a synthesis of several controlled environment experiments that we used to alter resource availability, to analyse endophyte concentrations and metabolic profiles in N. lolii infected ryegrass plants using both quantitative PCR (qPCR) and targeted metabolic profiling methods (Rasmussen et al. 2007, 2008b). The same plants were also exposed to insect herbivores, and a multiple regression analysis was performed to resolve differences between resource treatments in metabolic profiles, and to link the numbers of insects found on infected and non-infected plants to specific metabolites. This revealed that a range of non-alkaloid metabolites, and different balances between metabolites, might be involved in insect herbivore responses to endophyte infected ryegrass plants (Rasmussen et al. 2008a).

\section{Effects of resource supply on endophyte and alkaloid concentrations}

Endophyte produced alkaloids are critical in pasture based animal production systems: (1) for the protection of forage grasses from insect damage, but also (2) for their potential to harm grazing livestock. It would therefore be important to test, if, and how, changes in pasture management (e.g. nitrogen fertilisation) or the use of different cultivars (e.g. with intrinsically different carbohydrate contents) affect the synthesis and concentration of these alkaloids, given these external factors are altering the fundamental supply of resources to the fungus. Although a great number of field based studies has been performed to test for effects of season, weather, and management on alkaloid profiles and concentrations (for L. perenne see: Keogh 1983; Ball et al. 1995; Salminen and Grewal 2002; Hume and Barker 2005; for $S$. arundinaceus see: Lyons et al. 1986; Belesky et al. 1988; Arechevaleta et al. 1992; Malinowski et al. 1998b), controlled studies on individual environmental factors that would allow to predict effects of management practices like e.g. fertilisation, are unfortunately relatively rare. In tall fescue increased $\mathrm{N}$ availability tends to increase alkaloid concentrations (Lyons and Bacon 1984; Belesky et al. 1988; Arechevaleta et al. 1992), whereas in ryegrass, N supply seems to have no consistent effect (Stewart 1986; Lane et al. 1997; Hunt et al. 2005; Krauss et al. 2007). Almost no information is available on the effects of specific grass cultivars with intrinsically contrasting metabolic composition on consequent alkaloid concentrations (in the presence of endophytes). This is so even though it is well established that endophyte content and alkaloid accumulation can be affected by host genotypes (Easton et al. 2002).

In our controlled environment studies we tested the effects of carbohydrate levels in the host, and nitrogen availability on the concentrations of both the endophyte and alkaloids, using a combination of host, endophyte and resource supply conditions. We used two $L$. perenne cultivars differing intrinsically in carbohydrate content: 'AberDove' (high sugar levels) and 'Fennema' (normal sugar levels). These cultivars 
mainly differ in the concentrations of fructans, which are medium to high molecular weight water soluble carbohydrates (HMW WSCs), and the major storage sugar in vegetative tissues of ryegrass (Pollock and Jones 1979; Pavis et al 2001; Parsons et al. 2004). Individual seedlings of each cultivar were infected with one of three strains of endophytes: CScommon strain LP19 (produces peramine, lolitrem $\mathrm{B}$, and ergovaline), AR1 (produces peramine only), and AR37 (produces none of these three alkaloids, but epoxy-janthitrems), and compared with each other and endophyte-free plants. For a detailed description of experimental conditions and analytical methods see Rasmussen et al. (2007). Plants were grown at two different $\mathrm{N}$ levels resulting in a total blade $\mathrm{N}$ content of $3 \%$ in the 'low' $\mathrm{N}$, and of $4 \%$ in the 'high' $\mathrm{N}$ treatment. These $\mathrm{N}$ concentrations are representative for characteristically unfertilised ryegrass pastures grown extensively in a mixed sward with the N-fixing legume Trifolium repens, and mineral $\mathrm{N}$-fertilised intensive pastures, respectively (Parsons et al. 1991).

As changes in alkaloid concentrations at different resource availabilities could be due to changes in alkaloid production per unit endophyte (specific activity of fungal strain) or to changes in the amount of fungus per unit of tissue (endophyte concentration per se), we quantified fungal concentrations in the infected plants, using qPCR of endophyte specific genes, and fungal specific metabolites.

A major outcome of that study was that both endophyte and alkaloid (here we show peramine only) concentrations were strongly reduced (halved) in the high sugar cultivar 'AberDove' compared to 'Fennema' (Fig. 2a, b). High $\mathrm{N}$ levels had a similar effect (Fig. 2d, e), and these effects were additive, resulting in an overall reduction of endophyte, and alkaloid concentrations, of up to $75 \%$ in the high sugar cultivar when grown at high $\mathrm{N}$ (Rasmussen et al. 2007). Likewise mannitol, a very common polyol in fungi (Lewis and Smith 1967), and described in both endophyte infected tall fescue (Richardson et al. 1992) and ryegrass (Harwood 1954), was also reduced in 'AberDove' relative to 'Fennema' and at high N (Fig. 2c, f; Rasmussen et al. 2008b).

In our studies we demonstrated 'direct' linear relationships between fungal metabolite concentrations and the concentration of fungi in the same

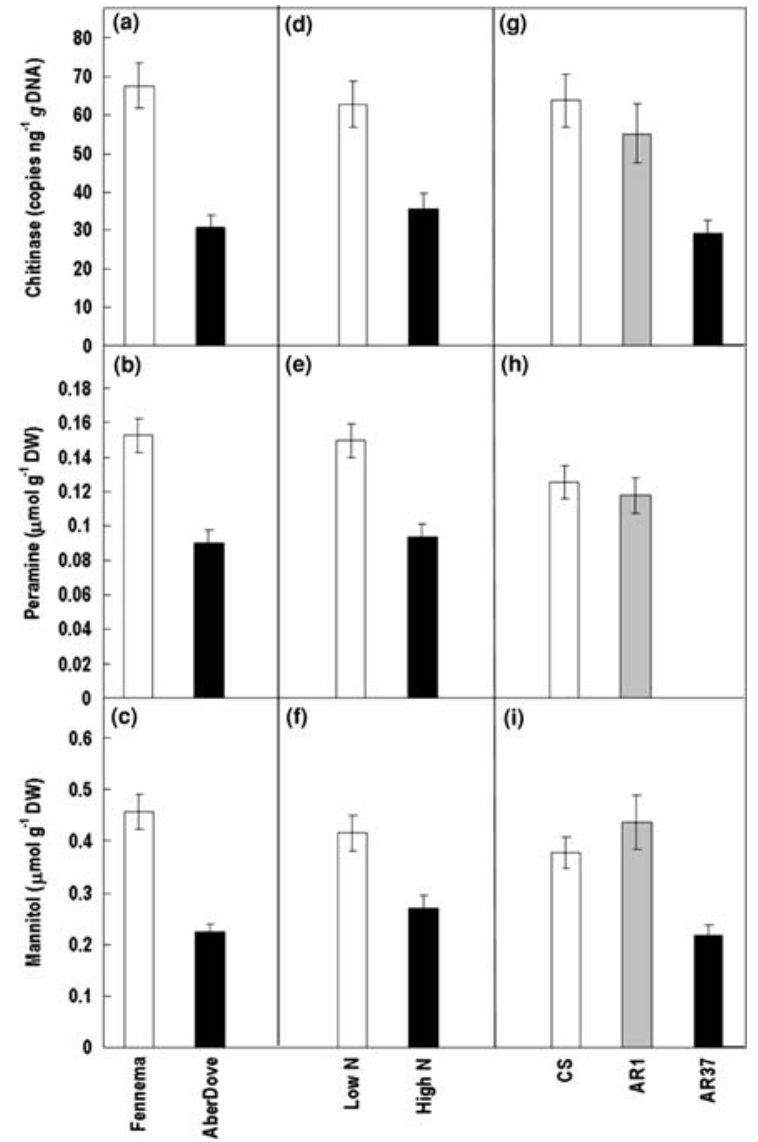

Fig. 2 Main effects of cultivar (a, b, $\mathbf{c}$; means of high and low $\mathrm{N}$ plants infected with CS, AR1, or AR37), N supply (d, e, f; means of plants from both cultivars infected with CS, AR1, or AR37) and endophytic strain (g, h, i; note for $\mathbf{h}$ : AR37 does not produce peramine; means of both cultivars grown at high and low $\mathrm{N}$ ) on concentrations of endophyte (chitinase copies; $\mathbf{a}, \mathbf{d}$, $\mathbf{g}$ ), peramine $(\mathbf{b}, \mathbf{e}, \mathbf{h})$ and mannitol $(\mathbf{c}, \mathbf{f}, \mathbf{i})$ in mature blades of endophyte infected L. perenne plants (bars SE)

tissues (Rasmussen et al. 2007, 2008b). Spiering et al. (2005) reported only a weak relationship between alkaloid and endophyte content, but these authors were looking across a range of tissues and tissue ages. Endophyte content is much higher in some tissues, e.g. sheaths, compared to mature blades, whereas, e.g. peramine concentrations are almost the same in these two tissues (Ball et al. 1997). Linear relationships between fungal metabolite concentrations and fungal amounts might be observable within a given tissue type, but would be less likely to be expected across different tissues. More general relationships between endophyte and alkaloid concentrations and endophyte/grass responses to environmental factors 
require far more attention, than has been common place, to the actual concentrations of endophytes, and to linking endophyte concentrations to alkaloid concentrations within a given tissue.

As to possible explanations for resource supply effects on endophyte concentrations we hypothesized that high nitrogen supply might increase plant growth more than fungal growth and so result in an overall 'dilution effect' (Rasmussen et al. 2008b). It would be interesting to test if other plant growth affecting nutrients (e.g. phosphorous) or treatments (e.g. temperature, light), have similar effects on endophyte concentrations. In contrast, this kind of 'dilution effect' seems not to be related to reduced endophyte concentrations in the high sugar cultivar 'AberDove' compared to 'Fennema', as we did not detect any differences in plant growth between the two cultivars (Rasmussen et al. 2008b). It could be argued that high sugar cultivars, which, as stated above, mainly differ in the concentrations of high molecular weight fructans, might have lower concentrations of low molecular weight sugars like glucose, fructose, and sucrose compared to 'Fennema'. These sugars are more likely to be transported to the apoplastic space and, analogous to models described for mycorrhizal and pathogenic fungi (Pfeffer et al. 1999; Hall and Williams 2000) might be the main source of carbon skeletons and energy for the heterotrophic endophytic fungus. Lower levels of these sugars could therefore impair fungal nutrition and growth, but we note here that, to date, it is not known (1) if endophytic Neotyphodium/Epichlö̈ fungi take up nutrients from the apoplastic space and/or from plant cells they are attached to, and (2) which metabolites are taken up by these fungi. Although we did not measure sugar concentrations in the apoplast, we showed that overall concentrations of glucose, fructose, and sucrose in the symbiotic tissue were quite similar in the two cultivars tested (Rasmussen et al. 2008b).

Another possible explanation might be cultivarspecific effects per se, as strong host $\times$ endophyte specificities have been shown previously to be determining factors for endophyte abundance/alkaloid accumulation (Easton et al. 2002; Saikkonen et al. 2004), but our experiments were not designed to test this hypothesis. However, our detailed analysis of metabolic profiles revealed that one of the 18 quantified free amino acids, L-methionine, was significantly higher in the high sugar cultivar
'AberDove' (2.4 fold) compared to 'Fennema' (Rasmussen et al. 2008b). L-methionine has been reported to act as an inhibitor of Claviceps microcephala growth and sporulation (Singh et al. 1972) and to induce resistance against Sclerospora graminicola in pearl millet (Sarosh et al. 2005). Clearly, further studies are needed to decipher mechanisms regulating endophytic growth and metabolite production in their host plants.

\section{Effects of $N$. lolii endophytes on host plant metabolic composition}

The endophyte studied by us is a heterotrophic organism which depends completely on macro- and micronutrients and energy produced or taken up by its autotrophic host, and so all metabolites produced by the endophyte are ultimately derived from plant metabolites. It is often argued that, based on total amounts of DNA, the endophyte represents only between 0.5 and $2 \%$ of the association (Young et al. 2005) implying that endophyte effects on host metabolism will be small. However, as pointed out earlier by us (Rasmussen et al. 2007), the haploid $N$. lolii genome is very small (the genome size of its sexual congener $E$. festucae has been estimated to be approximately $30 \mathrm{Mb}$; Kuldau et al. 1999) compared with the diploid ryegrass genome $\left(6.18 \times 10^{3} \mathrm{Mb}\right)$; any ratios determined based on total DNA are therefore heavily biased towards plant DNA. We have shown previously that the ratios of fungal compartments (single nuclei per fungal compartment) to plant cells determined by qPCR of copy numbers of endophyte specific single copy genes (one copy $=$ one nuclei) can be as high as 1:2 in infected mature blades (Rasmussen et al. 2007). The $40 \mathrm{Mb}$ genome of the filamentous fungus Neurospora crassa has been estimated to code for approximately 10,000 genes (Mannhaupt et al. 2003), but likewise the much larger plant genomes have been estimated to code for 10,000-60,000 genes (Messing et al. 2004). It is therefore likely that the presence of the endophyte and its metabolic activity can contribute substantially to the metabolism of the association. To test this hypothesis, we performed a metabolomics analysis in the same material as described above, and in which we quantified 66 major metabolic variables and compared the profiles in blades of each of the three 
endophyte infected grasses with each other and with those in the non-infected grasses (Rasmussen et al. 2008b). It is important to note here that all analyses were performed on whole blade tissue; it is therefore not possible to distinguish between fungal and plant metabolites except for those metabolites known to be produced by endophytes only (alkaloids, mannitol) or by plants only (plant secondary metabolites like e.g. chlorogenic acid).

A detailed description of the statistical analysis of our results based on principal components analysis with subsequent factor rotation can be found in Rasmussen et al. (2008b). Concentrations of 41 of the 66 metabolic variables were significantly different in endophyte infected compared to uninfected mature blades. A schematic representation of possible metabolic links between plant and fungal metabolites is shown in Fig. 5 and will be discussed below. Overall, endophyte infection resulted in a reduction of nitrogenous compounds. Seventeen out of 18 free amino acids, as well as nitrate, total $\mathrm{N}$, and total proteins were reduced; reductions of nitrate, L-asparagine and L-proline were very strong and are shown in Fig. 3a-c. Concomitantly, carbon compounds were increased in infected tissues (Rasmussen et al. 2008b), most strongly affected were sugars (shown as total water soluble carbohydrates; Fig. 4a), organic acids (especially quinate and shikimate, the precursors of aromatic acids; Fig. 4b), and phenolics (Fig. 4c; main phenolic in ryegrass blades is chlorogenic acid, the quinate ester of caffeic acid, Rasmussen et al. 2008b). A reduction of nitrate levels has been shown previously for endophyte infected tall fescue (Lyons et al. 1990; Belesky and Fedders 1996) and ryegrass (Hunt et al. 2005), but it is unclear which mechanisms lead to this reduction. Mycorrhizal fungi have been shown to regulate host plant $\mathrm{N}$ assimilation (Govindarajulu et al. 2005; Bailly et al. 2007), but since Neotyphodium endophytes largely are absent from the roots, other, probably more indirect, mechanisms seem to operate here. Although we have not analysed overall $\mathrm{C} / \mathrm{N}$ ratios, the much lower levels of L-asparagine in endophyte infected tissues are an indication of a higher $\mathrm{C}$ to $\mathrm{N}$ ratio compared to uninfected tissues, as this amino acid acts as an inert and stable $\mathrm{N}$ reserve (Lam et al. 1996) and is especially synthesized and stored in tissues with low $\mathrm{C}$ to $\mathrm{N}$ ratios (here: uninfected tissue).

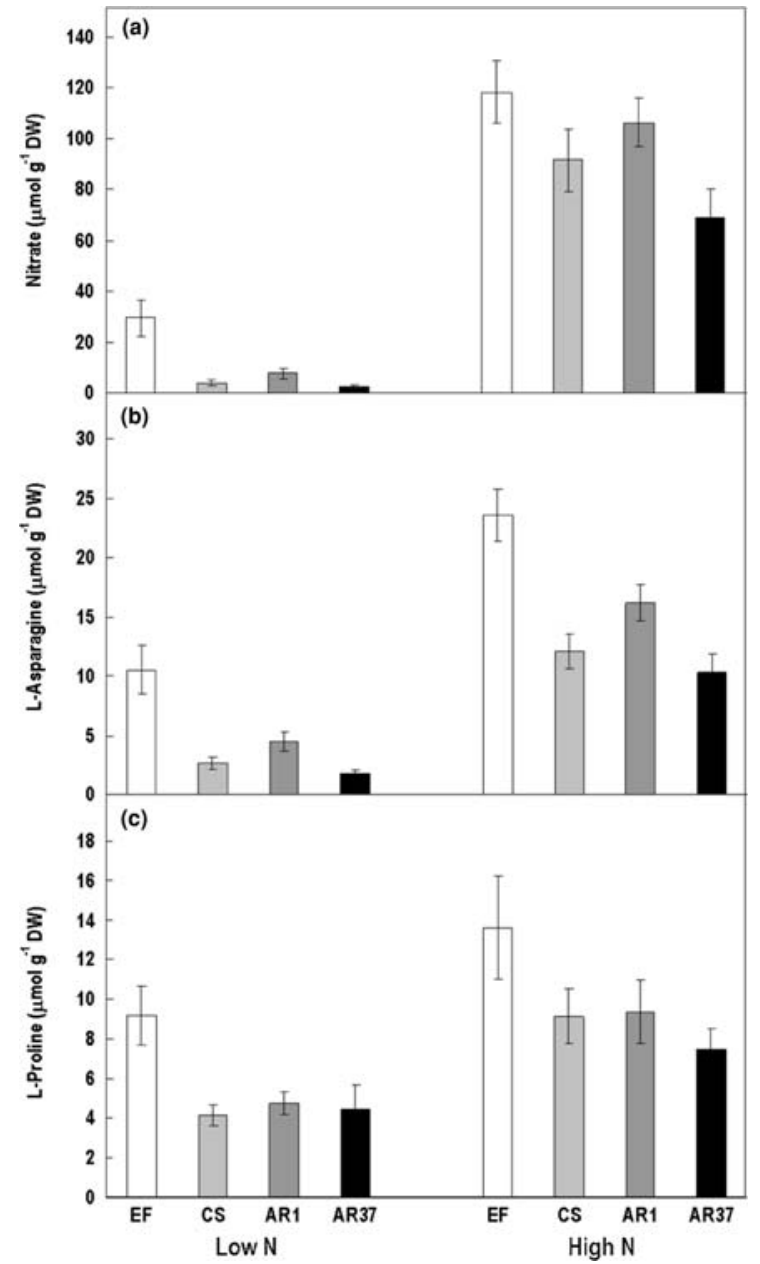

Fig. 3 Effects of endophyte infection at low and high $\mathrm{N}$ supply on concentrations of nitrate (a), L-asparagine (b), and L-proline (c) in mature blades of L. perenne plants (bars SE)

It is possible that the increase in carbon compounds is just due to reduced nitrate availability, and so reduced synthesis of nitrogenous compounds, in the tissue tested. However, at low $\mathrm{N}$ availability the effects of endophyte infection on the metabolic composition of the symbiotic tissue were generally stronger (Figs. 3, 4). At low N supply endophyte concentrations were also much higher (Fig. 2d; Rasmussen et al. 2007), it is therefore possible that the changes in metabolic composition are (also) due to increased sink strength of the heterotrophic endophyte on metabolites produced by its host. Increased sink strength has been shown to increase photosynthetic activity in host plants' source tissue and to be one of the drivers for changes in metabolic host plant 


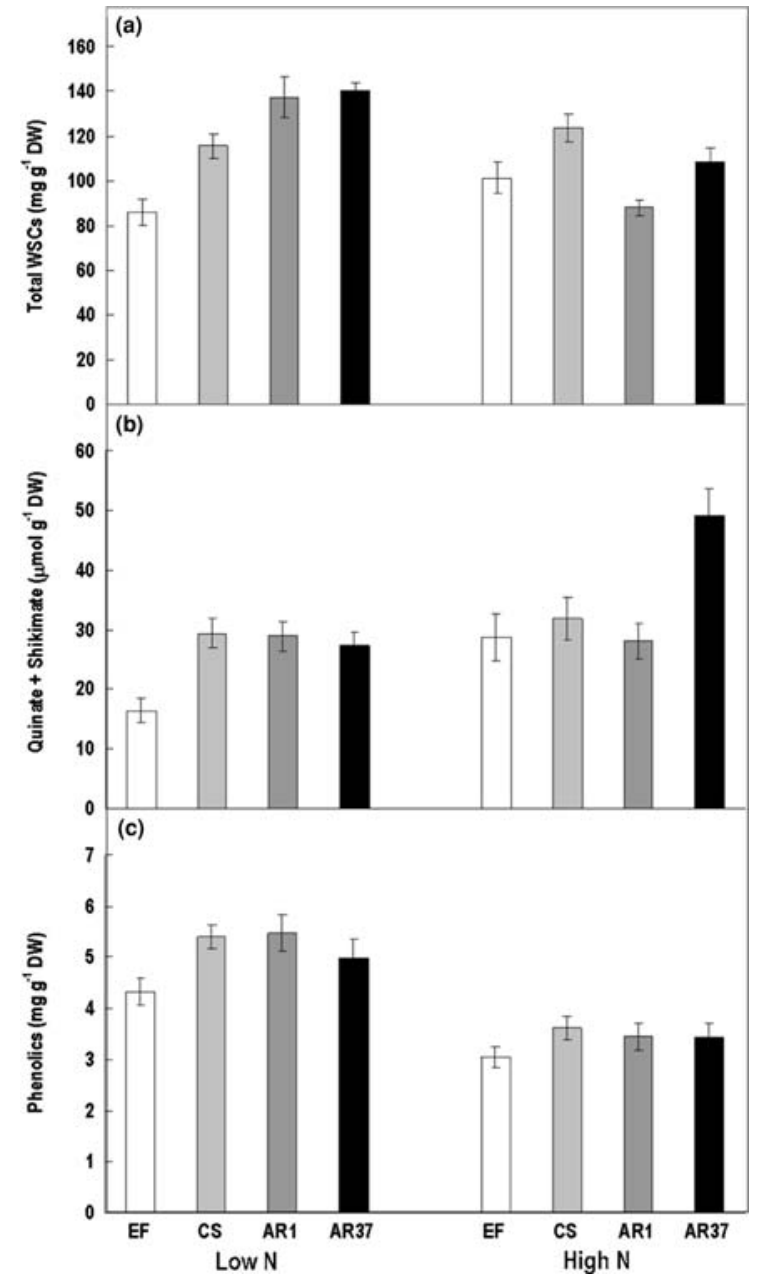

Fig. 4 Effects of endophyte infection at low and high N supply on concentrations of total WSCs (a), quinate and shikimate (b), and phenolics (c) in mature blades of $L$. perenne plants

composition in arbuscular mycorrhizal associations (Wright et al. 1998; Douds et al. 2000; Graham 2000; Pfeffer et al. 2001), but a major difference between Neotyphodium/Epichlö̈ and arbuscular mycorrhizal associations is the presence of an extensive extraradical hyphal net in the latter, resulting in a much larger total biomass of the heterotrophic mycorrhizae and so a much higher sink strength compared to the fungal associations studied here. In addition, the tissues analysed in our studies represent both source (plants' photosynthetic carbon fixation) and sink (heterotrophic fungus) tissue, making it very difficult to distinguish between source and sink processes. Nevertheless, negative impacts of Neotyphodium endophytes on plant performance and growth in natural ecosystems, especially under severe resource limitations (Cheplick et al. 1989, 2000; Faeth and Sullivan 2003; Cheplick 2004, 2007; Hesse et al. 2004; Faeth and Hamilton 2006), could result in higher concentrations of endophytes under these conditions (as seen in our studies), resulting in increased metabolic demands by endophytes on their host plants.

The organic acids quinate and shikimate are precursors for aromatic acids (Herrmann and Weaver 1999), which are required for phenylpropanoid biosynthesis. We have shown that quinate/shikimate as well as phenolics (mainly chlorogenic acid, Rasmussen et al. 2008b) were increased in endophyte infected ryegrass, consistent with reports from infected tall fescue (Malinowski et al. 1998a). It has also been reported that $N$. coenophialum infection of above ground tall fescue tissue affects concentrations and patterns of phenylpropanoids in the roots and that this improves plant resistance to soil nematode (Pratylenchus scribneri) infection (Bacetty et al. 2007). At this stage a discussion on possible mechanisms for increased levels of phenolics in endophyte infected tissues is very speculative, but it has been suggested that endophytes might induce a weak resistance response in their host plants (Malinowski and Belesky 2000), comparable to effects of mycorrhizal colonisation (Harrison and Dixon 1993; Volpin et al. 1994; Hohnjec et al. 2005), thereby increasing the biosynthesis of phenylpropanoids. A strong induction of host plant secondary metabolites has also been shown in Ustilago maydis infected maize (Doehlemann et al. 2008), and in Brassica rapa plants infected with a range of pathogenic fungi (Abdel-Farid et al. 2009). Associated with the induction of secondary metabolites and resistance responses in plants is the production of reactive oxygen species (ROS; Torres and Dangl 2005; Takemoto et al. 2007). Recent studies of the association between Epichlö̈festucae and perennial ryegrass have shown that ROS production plays a critical role in the regulation of in planta endophytic hyphal morphogenesis and growth (Tanaka et al. 2006; Tanaka et al. 2008).

\section{Joint plant and fungal metabolic networks}

A hypothetical schematic representation of endophyte metabolic effects and possible metabolic network connections in ryegrass blades infected with $N$. lolii 
strain Lp19 (CS) is shown in Fig. 5. Please note that this hypothetical scheme only shows those metabolites and plant quality parameters which were actually measured in our studies (except for acetyl CoA, which we have not analysed, but which is central to most processes described below). Many metabolites known to be important intermediates of metabolic pathways, like e.g. phosphorylated sugars and CoA esters, as well as metabolites usually present in very low concentrations, like e.g. phytohormones, were not detected by our analytical methods. The arrows and lines in Fig. 5 do not represent a direct biosynthetic

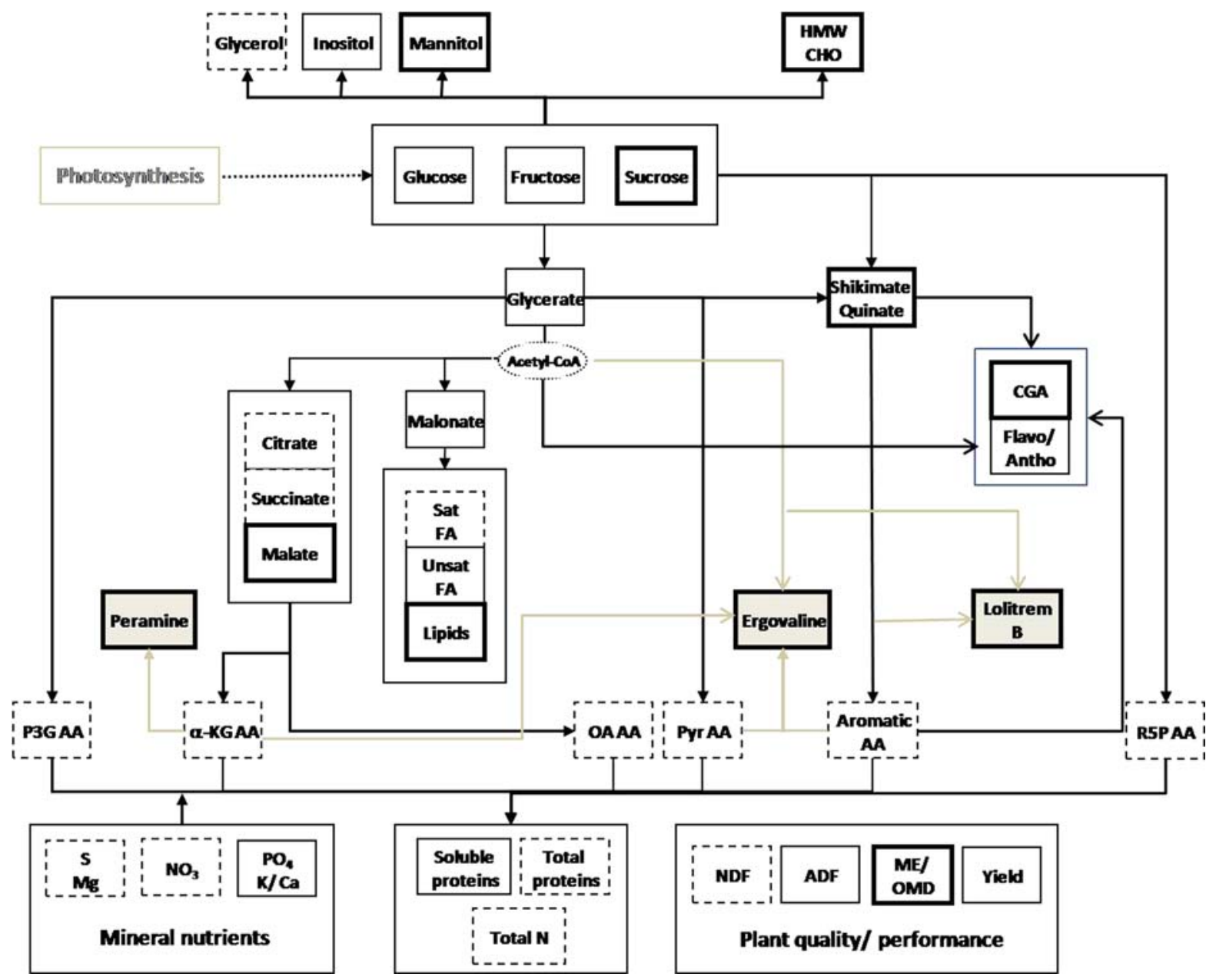

Fig. 5 Hypothetical schematic representation of metabolic endophyte effects and possible metabolic network connections in L. perenne mature blades infected with N. lolii Lp19 (CS) strain. Up-regulated metabolites are shown in bold solid boxes, down-regulated metabolites in dashed boxes, and unchanged metabolites in fine solid boxes (for details of analytical methods see Rasmussen et al. 2008b). Shown are only metabolites/ quality parameters that were quantified in our analyses, except for acetyl CoA (dotted circle). Arrows and lines do not represent direct biochemical relationships, but rather indicate possible connections between those metabolites. Metabolites produced exclusively by the endophytic fungus and connections to them are highlighted in grey. Amino acids synthesized from the same precursor were grouped: $\mathrm{P} 3 \mathrm{G}$ AA-L-serine, L-cysteine (not quantified), L-glycine derived from 3-phosphoglycerate; $\alpha-\mathrm{KG}$ AA-L-glutamate, L-glutamine, L-proline, L-arginine derived from $\alpha$-ketoglutarate; OA AA-L-aspartate, L-asparagine, L-methionine, L-threonine, L-lysine, L-isoleucine derived from oxaloacetate; Pyr AA-L-alanine, L-valine, L-leucine derived from pyruvate; PEP + E4P AA-L-phenylalanine, L-tyrosine, L-tryptophan derived from erythrose 4-phosphate and phosphoenolpyruvate (Stryer 2000). Fatty acids were grouped into saturated fatty acids (Sat FA; only C17:0 and C18:0 were downregulated) and unsaturated fatty acids (Unsat FA). Plant quality parameters were analysed by near-infrared spectroscopy: $N D F$ neutral detergent fibre; $A D F$ acid detergent fibre; $M E$ metabolisable energy; $O M D$ organic matter digestibility 
relationship between the depicted metabolites, but rather a simplified scheme of possible metabolic network connections. To further simplify this scheme, we have grouped some of the analysed metabolites like e.g. saturated and unsaturated fatty acids (Sat FA, Unsat FA), and amino acids (based on their common precursor; Stryer 2000).

As stated above, our analyses does not enable us to define if and to what extent the individual metabolites are produced by the plant or the fungus, and we can also make no statements as to which plant metabolites are taken up by the endophytic fungi and further metabolised. Detailed studies on metabolite uptake have been performed for mycorrhizal associations (Shachar-Hill et al. 1995; Solaiman and Saito 1997; Pfeffer et al. 1999), and for some biotrophic fungal pathogens (Clark and Hall 1998; Hall et al. 1992; Hall and Williams 2000) indicating that glucose is the preferred sugar to be taken up by these fungi, but unfortunately this kind of information is still lacking for Neotyphodium/Epichlö - grass associations. The only metabolites analysed here known to be produced exclusively by the endophytic fungal strain N. lolii Lp19 are the alkaloids peramine, lolitrem B, and ergovaline (highlighted in grey in Fig. 5). Mannitol is most likely a fungal metabolite and was found in high concentrations in endophyte infected blades, but we also detected traces of this polyol in some uninfected samples. Therefore, we cannot exclude that ryegrass itself can produce this compound, and it is known to accumulate in more than 50 families of the Angiosperms (Lewis and Smith 1967).

The unusual pyrrolopyrazine peramine has so far been shown to be produced only by Neotyphodium/ Epichlö fungi (Siegel et al. 1990). Although no experimental data are available for the biosynthetic precursors of this alkaloid, its structure suggests that it is derived from the two amino acids arginine and proline (Rowan 1993), both belonging to the $\alpha$-ketoglutarate amino acid family ( $\alpha$-KG AA). Recently, a non-ribosomal peptide synthetase catalysing peramine formation has been isolated from $N$. lolii, and the knock-out of the encoding gene (perA) in E. festucae has been shown to result in a loss of peramine (and associated feeding deterrent activity against Argentine stem weevil-ASW) in plants infected with the mutant strain (Tanaka et al. 2005).

Although the alkaloid lolitrem B seems to be specific for Neotyphodium/Epichloe fungi, other indole-diterpenoids like paspaline and paxilline are produced by other fungal genera as well (Springer et al. 1975; Springer and Clardy 1980). Indolediterpenoids have a common cyclic diterpene core, derived from geranylgeranyl diphosphate (GGDP), and an indole group (Saikia et al. 2008). The starting compound for GGDP is isopentenyl diphosphate, which is produced from acetyl CoA (indicated as a grey arrow from acetyl CoA to lolitrem B in Fig. 5). The indole ring is most likely derived from a precursor of tryptophan (an aromatic amino acid; de Jesus et al. 1983). The enzymatic biosynthesis of lolitrem B in E. festucae and N. lolii is encoded by a gene cluster of at least 10 genes, which also contains a gene for GGDP synthase (Young et al. 2005, 2006), making it likely that GGDP is produced by the fungus itself. The knock-out of one of the genes (ltmM) in $E$. festucae resulted in a loss of lolitrem $\mathrm{B}$ in plants infected with the mutant strain (Young et al. 2005).

Ergot alkaloids have been shown to be produced via isoprenylation of the aromatic amino acid tryptophan with dimethylallylpyrophosphate (synthesized from acetyl $\mathrm{CoA}$ ) to form dimethylallyltryptophan (DMAT), which is converted to lysergic acid (Lane et al. 2000; Tudzynski et al. 2001). A gene coding for DMAT synthase has been cloned from Neotyphodium sp. isolate Lp1, and the knock-out of this gene abolished ergovaline production in ryegrass plants infected with the mutant strain (Wang et al. 2004). Ergovaline, the main ergotpeptide found in Neotyphodium/Epichlo $\ddot{e}$ infected plants, is produced by transfer of the amino acids L-alanine, L-valine (both derived from pyruvate) and L-proline (from $\alpha$-ketoglutarate) to lysergic acid by a multifunctional enzyme complex, which has also been identified from Neotyphodium. sp. Lp1 (Panaccione et al. 2003).

Although endophyte alkaloid biosynthesis can be seen as a sink for carbon and nitrogen compounds produced by the host plant, a closer look at actual changes of metabolite concentrations and total alkaloid concentrations indicates that this sink is most probably very small. In the case of peramine $\left(\mathrm{C}_{12} \mathrm{H}_{17} \mathrm{~N}_{5} \mathrm{O}\right)$, the most abundant of all analysed alkaloids, we found that its concentration at low $\mathrm{N}$ was $0.15 \mu \mathrm{mol} / \mathrm{g}$ DW (Fig. 2e), but the concentrations of L-arginine and L-proline (likely precursors of peramine) were much more reduced in endophyte (CS) infected compared to uninfected plants by 
approximately $5 \mu \mathrm{mol} / \mathrm{g}$ DW each (Rasmussen et al. 2008b; L-arginine from 18 to $13 \mu \mathrm{mol} / \mathrm{g} \mathrm{DW}$; L-proline from 9 to $4 \mu \mathrm{mol} / \mathrm{g} \mathrm{DW}$, Fig. 3c). Compared to peramine, ergovaline $\left(\mathrm{C}_{29} \mathrm{H}_{35} \mathrm{~N}_{5} \mathrm{O}_{5}\right)$ and lolitrem $\mathrm{B}$ $\left(\mathrm{C}_{42} \mathrm{H}_{55} \mathrm{NO}_{7}\right)$ are present in infected mature blades in much lower concentrations of approximately $0.5 \mathrm{nmol} / \mathrm{g}$ DW and $1.2 \mathrm{nmol} / \mathrm{g} \mathrm{DW}$, respectively (Rasmussen et al. 2008b). We suggest therefore that the changes in metabolic profiles seen in our study are not predominantly caused by alkaloid biosynthesis, but rather by more general metabolic processes occurring in the fungus like e.g. biosynthesis of proteins, lipids, and cell walls, and maintenance and growth respiration.

Many open questions remain as to how and to what extent the endophyte affects plant metabolism. Some of the most important questions which need to be addressed in future studies are: (1) Which metabolites are taken up by the endophyte? (2) Are these metabolites taken up from the apoplast or from plant cells the endophyte is attached to? (3) Which transporters are involved? (4) Does the endophyte affect nitrate uptake/transport from host roots? (5) Does endophyte infection induce host genes involved in secondary plant metabolite production (e.g. genes of the phenylpropanoid pathway)?

\section{Effects of $N$. lolii endophytes on insect herbivores}

Resistance against herbivory, notably damage by potentially devastating pest attacks e.g. by Argentine Stem Weevil, is an unquestionable benefit of endophyte infection to plant fitness, in both natural and commercial (agricultural) contexts. Usually, this fitness benefit is ascribed to the production of antiherbivorous alkaloids (Siegel et al. 1990; Rowan and Latch 1994; Bush et al. 1997; Schardl et al. 2007). However, the widespread changes seen in metabolic profiles, and especially the shift to higher carbon/ nitrogenous metabolite ratios, and potential stimulation of defense compounds make it arguable that effects on insect herbivores might be causally related to metabolic factors other than the alkaloids alone (Brown et al. 2002; Douglas 2006; Douglas et al. 2006), or at least that other factors can modulate alkaloid impacts.. We exposed the same plant material used in the studies discussed above (Rasmussen et al. 2007, 2008b) to a suite of insects (aphid spp., thrips, mites) and assessed the impacts on the insect populations (Rasmussen et al. 2008a). Different insect species responded very differently to endophyte infected plants. Aphids belonging to the genus Rhopalosiphum were much more abundant on AR1 infected plants than on endophyte free, CS or AR37 infected plants (Fig. 6a). In contrast, Sitobion frageriae aphids were much more abundant on AR37 infected plants (Fig. 6b). This clearly shows that different insect herbivores (here phloem sucking aphids) may be affected in a different way, even when feeding on the same plant tissue. Numbers of both, S. frageriae and mites, were highest on AR37 infected and lowest on endophyte free plants (Fig. 6b, c).

We regressed numerical responses of the individual insect populations to the analysed metabolites to link each of these responses to endophyte infection (Rasmussen et al. 2008a). We found that apterate Rhopalosiphum spp. correlated negatively to lolitrem B, lipids, and fibre content, and positively to peramine and malonate. In contrast, apterate $S$. frageriae correlated negatively to peramine and histidine, and positively to sugars. The responses of mites could not be linked to any of the alkaloids, but was positively correlated with shikimate, L-serine, and the fatty acid C16:0. In general, we found more thrips and mites on plants grown with high $\mathrm{N}$ supply, while numbers of aphids were slightly reduced on these plants (Rasmussen et al. 2008a). As would be expected (despite common perceptions) aphid populations were not affected by higher sugar levels in 'AberDove' compared to 'Fennema' (Rasmussen et al. 2008a). Although this type of analysis does not allow the establishment of direct and causal relationships between a certain metabolite and insect population responses, the differential pattern of these responses is intriguing and warrants further metabolomics studies on the effects of non-alkaloid metabolites on insect and other herbivores. A recent study also performed in our lab and using untargeted direct infusion ion trap mass spectrometry revealed the presence of formerly unknown compounds produced in endophyte infected plants (Cao et al. 2008). Some of these compounds belong to the class of cyclic oligopeptides, which have been shown to be potentially antimicrobial (Arai et al. 1973, Strobel and Hess 1997; Seto et al. 2007) and it is therefore possible that some of the plant protecting effects seen in 
Fig. 6 Effects of numbers of apterate Rhopalosiphum spp. (a), apterate $S$. frageriae (b), and mites (c) on shoots of L. perenne plants endophyte infection on

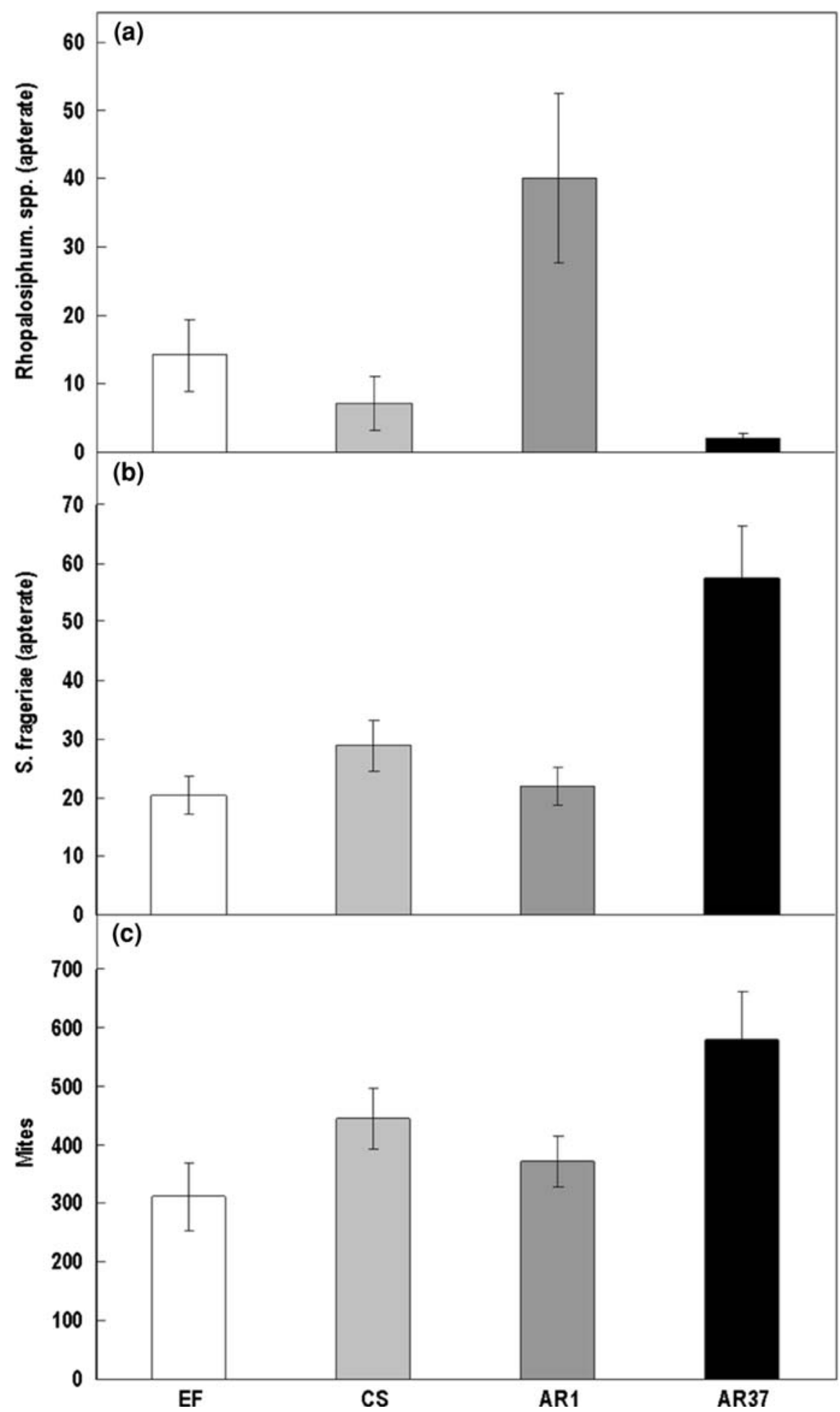

endophyte infected plants are due to these or other, still completely unknown, endophyte specific compounds.
Endosymbioses present a particular challenge to using metabolic profiling to characterise metabolic processes in the endosymbiotic organisms: 
because more than one organism genome/metabolome is involved, (2) many metabolites are identical in both organisms, (3) it is unclear to what extent one organism is using (in effect) the other's metabolic network, to synthesise a given metabolite, and (4) because there is uncertainty over the abundance of the endosymbiont in the host population. The combined metabolic profile of the host/endosymbiont association as reported by us is arguably only descriptive, and we have proposed, from our studies, how metabolic profiles can be presented as simply another measured variable in a conventional critical experimental design where a series of treatments/ factors have been used to perturb the system. This may reveal extra insights into the fitness consequences that a given profile ascribes.

But because differences in fitness between individuals in a population will mean shifts in the prevalence of e.g. endophyte infected individuals, we propose it is important to report wherever possible, the quantity (e.g. as a concentration) of endosymbiont present within any one plant's tissue, as well as across the population.

Biotechnological advances increasingly aim to modify plant metabolic composition through the introduction of e.g. endophytic strains with novel alkaloids. It is therefore critical to ensure that e.g. a toxic compound usually accumulated at low levels, does not become unexpectedly a highly accumulated compound, due purely to an increased population of e.g. the endosymbiont within one organisms' tissues, or an increased prevalence of that symbiosis at the population level brought about e.g. by unintended (and unrelated to the alkaloids of interest) effects on the metabolic profiles of the symbiotic association. Combinations of metabolomics (and other 'omics' approaches) and ecological sciences are valuable to assess the wider impacts of shifts in metabolic profiles.

Acknowledgments We would like to thank Dr. C. Voisey and Mr. M. Christensen (AgResearch Grasslands, Palmerston North, NZ), and Prof. H. Koga (Ishikawa Prefectural University, Ishikawa, Japan) for providing us with the original micrographs shown in Fig. 1a, b. This review is based partially on work funded by the New Zealand Foundation for Research, Science and Technology (contracts C10X0203 and PRJ10333-ECOS-AGR), and by grants from the Canadian Natural Sciences and Engineering Research Council and the Ontario Ministry of Agriculture, Food and Rural Affairs.

\section{References}

Abdel-Farid IB, Jahangir M, van den Hondel CAMJJ et al (2009) Fungal infection-induced metabolites in Brassica rapa. Plant Sci 176:608-615. doi:10.1016/j.plantsci.2009. 01.017

Amalric C, Sallanon H, Monnet F et al (1999) Gas exchange and chlorophyll fluorescence in symbiotic and non-symbiotic ryegrass under water stress. Photosynthetica 37:107-112. doi:10.1023/A:1007027131613

Arai T, Mikami Y, Fukushima K et al (1973) A new antibiotic, leucinostatin, derived from Penicillium lilacinum. J Antiobiot 26:157-161

Arechevaleta M, Bacon CW, Plattner RD et al (1992) Accumulation of ergopeptide alkaloids in symbiotic tall fescue grown under deficits of soil water and nitrogen fertiliser. Appl Environ Microbiol 58:857-861

Bacetty AA, Snook ME, Glenn AE (2007) Nematotoxic effects of endophyte-infected tall fescue toxins and extracts in an in vitro bioassay using the nematode Pratylenchus scribneri. In: Popay AJ, Thorn ER et al (eds) Proceedings of the 6th international symposium on fungal endophytes of grasses. Grasslands research and practice series no. 13. New Zealand Grassland Association, Dunedin, p 357

Bailly J, Debaud J-C, Verner M-C et al (2007) How does a symbiotic fungus modulate expression of its host-plant nitrite reductase? New Phytol 175:155-165. doi:10.1111/ j.1469-8137.2007.02066.x

Ball OJP, Prestidge RA, Sprosen JM (1995) Interrelationships between Acremonium lolii, peramine and lolitrem B in perennial ryegrass. Appl Environ Microbiol 61:1527-1533

Ball OJ-P, Barker GM, Prestidge RA et al (1997) Distribution and accumulation of the alkaloid peramine in Neotyphodium lolii-infected perennial ryegrass. J Chem Ecol 23:14191434. doi:10.1023/B:JOEC.0000006473.26175.19

Belesky DP, Fedders JM (1996) Does endophyte influence regrowth of tall fescue? Ann Bot (Lond) 78:499-505. doi: 10.1006/anbo.1996.0147

Belesky DP, Stuedemann JA, Plattner RD et al (1988) Ergopeptine alkaloids in grazed tall fescue. Agron $\mathrm{J} 80$ : 209-212

Brown ASS, Simmonds MSJ, Blaney WM (2002) Relationship between nutritional composition of plant species and infestation levels of thrips. J Chem Ecol 28:2399-2409. doi:10.1023/A:1021471732625

Bush LP, Wilkinson HH, Schardl CL (1997) Bioprotective alkaloids of grass-fungal endophyte symbioses. Plant Physiol 114:1-7

Cao M, Koulman A, Johnson LJ et al (2008) Advanced datamining strategies for the analysis of direct-infusion ion trap mass spectrometry data from the association of perennial ryegrass with its endophytic fungus, Neotyphodium lolii. Plant Physiol 146:1501-1514. doi:10.1104/pp.107.112458

Cheplick GP (2004) Recovery from drought stress in Lolium perenne (Poaceae): are fungal endophytes detrimental? Am J Bot 91:1960-1968. doi:10.3732/ajb.91.12.1960

Cheplick GP (2007) Costs of fungal endophyte infection in Lolium perenne genotypes from Eurasia and North Africa under extreme resource limitation. Environ Exp Bot 60:202-210. doi:10.1016/j.envexpbot.2006.10.001 
Cheplick GP, Clay K, Marks S (1989) Interactions between infection by endophytic fungi and nutrient limitation in the grasses Lolium perenne and Festuca arundinacea. New Phytol 111:89-97. doi:10.1111/j.1469-8137.1989. tb04222.x

Cheplick GP, Perera A, Koulouris K (2000) Effect of drought on the growth of Lolium perenne genotypes with and without fungal endophytes. Funct Ecol 14:657-667. doi: 10.1046/j.1365-2435.2000.00466.x

Christensen MJ, Leuchtmann A, Rowan DD et al (1993) Taxonomy of Acremonium endophytes of tall fescue (Festuca arundinacea), meadow fescue (Festuca pratensis) and perennial ryegrass (Lolium perenne). Mycol Res 97:1083-1092. doi:10.1016/S0953-7562(09)80509-1

Christensen MJ, Bennett RJ, Ansari HA et al (2008) Epichloë endophytes grow by intercalary hyphal extension in elongating grass leaves. Fungal Genet Biol 45:84-93. doi: 10.1016/j.fgb.2007.07.013

Clark JIM, Hall JL (1998) Solute transport into healthy and powdery mildew-infected leaves of pea and uptake by powdery mildew mycelium. New Phytol 140:261-269. doi:10.1046/j.1469-8137.1998.00263.x

Clay K, Schardl C (2002) Evolutionary origins and ecological consequences of endophyte symbiosis with grasses. Am Nat 160:S99-S127. doi:10.1086/342161

de Jesus AE, Gorst-Allman CP, Steyn PS et al (1983) Tremorgenic mycotoxins from Penicillium crustosum. Biosynthesis of penitrem A. J Chem Soc Perk T 1: 1863-1868

Doehlemann G, Wahl R, Horst RJ et al (2008) Reprogramming a maize plant: transcriptional and metabolic changes induced by the fungal biotroph Ustilago maydis. Plant J 56:181-195. doi:10.1111/j.1365-313X.2008.03590.X

Douds DD, Pfeffer PE, Shachar-Hill Y (2000) Carbon partitioning, cost and metabolism of arbuscular mycorrhizae in arbuscular mycorrhizas: physiology and function. In: Kapulnick Y, Douds DD Jr (eds) Arbuscular mycorrhizas: molecular biology and physiology. Kluwer Academic Publishers, Dordrecht

Douglas AE (2006) Phloem-sap feeding by animals: problems and solutions. J Exp Bot 57:747-754. doi:10.1093/jxb/ erj067

Douglas AE, Price DRG, Minto LB et al (2006) Sweet problems: insect traits defining the limits to dietary sugar utilization by the pea aphid, Acyrthosiphon pisum. J Exp Bot 209:1395-1403

Easton HS, Latch GCM, Tapper BA et al (2002) Ryegrass host genetic control of concentrations of endophyte-derived alkaloids. Crop Sci 42:51-57

Faeth SH, Sullivan TJ (2003) Mutualistic asexual endophytes in a native grass are usually parasitic. Am Nat 161:310 325. doi: $10.1086 / 345937$

Faeth SH, Hamilton CE (2006) Does an asexual endophyte symbiont alter life stage and long-term survival in a perennial host grass? Microb Ecol 52:748-755. doi: 10.1007/s00248-006-9123-Z

Fletcher LR, Easton HS (1997) The evaluation of use of endophytes for pasture improvement. In: Bacon CW, Hill NS (eds) Proceedings of the 3rd international symposium on Neotyphodium/grass interactions. Plenum Press, New York, p 209
Gallagher RT, Hawkes AD, Steyn PS et al (1984) Tremorgenic neurotoxins from perennial ryegrass causing ryegrass staggers disorder of livestock - Structure elucidation of Lolitrem-B. J Chem Soc Chem Commun 61:4-616

Govindarajulu M, Pfeffer PE, Jin H et al (2005) Nitrogen transfer in the arbuscular mycorrhizal symbiosis. Nature 435:819-823. doi: $10.1038 /$ nature 03610

Graham JH (2000) Assessing costs of arbuscular mycorrhizal symbiosis agroecosystems fungi. In: Podila GK, Douds DD Jr (eds) Current advances in Mycorrhizae research. APS Press, St. Paul

Hahn M, Mendgen K (2001) Signal and nutrient exchange at biotrophic plant-fungus interfaces. Curr Opin Plant Biol 4:322-327. doi:10.1016/S1369-5266(00)00180-1

Hall JL, Williams LE (2000) Assimilate transport and partitioning in fungal biotrophic interactions. Aust J Plant Physiol 27:549-560

Hall JL, Aked J, Gregory AJ (1992) Carbon metabolism and transport in a biotrophic fungal association. In: Pollock CJ, Farrar JF, Gordon AJ et al (eds) Carbon partitioning within and between organisms. Bios Scientific Publishers, Oxford, pp 181-198

Harrison MJ, Dixon RA (1993) Isoflavonoid accumulation and expression of defense gene transcripts during the establishment of vesicular-arbuscular mycorrhizal associations in roots of Medicago truncatula. Mol Plant Microbe Interact 6:643-654

Harwood VD (1954) Analytical studies on the carbohydrates of grasses and clover. VII. The isolation of D-mannitol from perennial ryegrass (Lolium perenne L.). J Sci Food Agric 5:453-455. doi:10.1002/jsfa.2740050911

Herrmann KM, Weaver LM (1999) The shikimate pathway. Annu Rev Plant Physiol Plant Mol Biol 50:473-503. doi: 10.1146/annurev.arplant.50.1.473

Hesse U, Schöberlein W, Wittenmayer L et al (2003) Effects of Neotyphodium endophytes on growth, reproduction and drought-stress tolerance of three Lolium perenne L. genotypes. Grass Forage Sci 58:407-415. doi:10.1111/ j.1365-2494.2003.00393.x

Hesse U, Hahn H, Andreeva K, Förster K et al (2004) Investigations on the influence of Neotyphodium endophytes on plant growth and seed yield of Lolium perenne genotypes. Crop Sci 44:1689-1695

Hesse U, Schöberlein W, Wittenmayer L et al (2005) Influence of water supply and endophyte infection (Neotyphodium spp.) on vegetative and reproductive growth of two Lolium perenne L. genotypes. Eur J Agron 22:45-54. doi: 10.1016/j.eja.2003.12.002

Hinton DM, Bacon CW (1985) The distribution and ultrastructure of the endophyte of toxic tall fescue. Can J Bot 63:36-42

Hohnjec N, Vieweg MF, Pühler A et al (2005) Overlaps in the transcriptional profiles of Medicago truncatula roots inoculated with two different Glomus fungi provide insights into the genetic program activated during arbuscular mycorrhiza. Plant Physiol 137:1283-1301. doi: 10.1104/pp.104.056572

Hume DE, Barker DJ (2005) Growth and management of endophytic grasses in pastoral agriculture. In: Roberts CA, West CP, Spiers DE (eds) Neotyphodium in cool-season grasses. Blackwell Publishing Professional, Iowa 
Hunt MG, Rasmussen S, Newton PCD et al (2005) Near-term impacts of elevated $\mathrm{CO}_{2}$, nitrogen and fungal endophyteinfection on perennial ryegrass: growth, chemical composition and alkaloid production. Plant Cell Environ 28:1345-1354. doi:10.1111/j.1365-3040.2005.01367.x

Keogh RG (1983) Ryegrass staggers: management and control. In: Proceedings of the NZ Grassland Association, vol. 44. Blenheim, p 248

Krauss J, Harri SA, Bush L et al (2007) Effects of fertilizer, fungal endophytes and plant cultivar on the performance of insect herbivores and their natural enemies. Funct Ecol 21:107-116. doi:10.1111/j.1365-2435.2006.01216.x

Kuldau GA, Tsai HF, Schardl CL (1999) Genome sizes of Epichlö̈ species and anamorphic hybrids. Mycologia 91:776-782. doi:10.2307/3761531

Lam H-M, Coschigano KT, Oliveira IC et al (1996) The molecular genetics of nitrogen assimilation into amino acids in higher plants. Annu Rev Plant Physiol 47:569593. doi:10.1146/annurev.arplant.47.1.569

Lane GA, Tapper BA, Davies E (1997) Effect of growth conditions on alkaloid concentrations in perennial ryegrass naturally infected with endophyte. In: Bacon CW, Hill AC et al (eds) Proceedings of the 3rd international symposium on Neotyphodium/grass interactions. Plenum Press, New York, p 179

Lane GA, Christensen MJ, Miles CO (2000) Coevolution of fungal endophytes with grasses: the significance of secondary metabolites. In: Bacon CW, White JF Jr (eds) Microbial endophytes. Marcel Dekker, New York, pp 341-388

Leuchtmann A (1993) Systematics, distribution, and host specificity of grass endophytes. Nat Toxins 1:150-162. doi: $10.1002 / n t .2620010303$

Lewis DH, Smith DC (1967) Sugar alcohols (polyols) in fungi and green plants. New Phytol 66:143-184. doi:10.1111/ j.1469-8137.1967.tb05997.x

Lyons PC, Bacon CW (1984) Ergot alkaloids in tall fescue infected with Sphacelia typhina. Phytopathology 75:501

Lyons PC, Plattner RD, Bacon CW (1986) Occurrence of peptide and clavine ergot alkaloids in tall fescue grass. Science 232:487-489. doi:10.1126/science.3008328

Lyons PC, Evans JJ, Bacon CW (1990) Effects of the fungal endophyte Acremonium coenophialum on nitrogen accumulation and metabolism in tall fescue. Plant Physiol 92:726-732. doi:10.1104/pp.92.3.726

Malinowski DP, Belesky DP (2000) Adaptations of endophyteinfected cool-season grasses to environmental stresses: mechanisms of drought and mineral stress tolerance. Crop Sci 40:923-940

Malinowski DP, Alloush GA, Belesky DP (1998a) Evidence for chemical changes on the root surface of tall fescue in response to infection with the fungal endophyte Neotyphodium coenophialum. Plant Soil 205:1-12. doi: 10.1023/A: 1004331932018

Malinowski DP, Belesky DP, Hill NS et al (1998b) Influence of phosphorus on the growth and ergot alkaloid content of Neotyphodium coenophialum-infected tall fescue (Festuca arundinacea Schreb.). Plant Soil 198:53-61. doi:10.1023/ A:1004279401196

Mannhaupt G, Montrone C, Haase D et al (2003) What's in the genome of a filamentous fungus? Analysis of the
Neurospora genome sequence. Nucleic Acids Res 31:1944-1954. doi:10.1093/nar/gkg293

Messing J, Bharti AK, Karlowski WM et al (2004) Sequence composition and genome organization of maize. Proc Natl Acad Sci USA 101:14349-14354. doi:10.1073/pnas. 0406163101

Müller CB, Krauss J (2005) Symbiosis between grasses and asexual fungal endophytes. Curr Opin Plant Biol 8:450456. doi:10.1016/j.pbi.2005.05.007

Panaccione DG, Tapper BA, Lane GA et al (2003) Biochemical outcome of blocking the ergot alkaloid pathway of a grass endophyte. J Agric Food Chem 51:6429-6437. doi: $10.1021 /$ jf0346859

Parsons AJ, Harvey A, Woledge J (1991) Plant/animal interactions in continuously grazed mixtures. I. Differences in the physiology of leaf expansion and the fate of leaves of grasses and clover. J Appl Ecol 28:619-634. doi:10.2307/ 2404572

Parsons AJ, Rasmussen S, Xue H et al (2004) Some 'high sugar grasses' don't like it hot. Proc NZGA 66:265-272

Pavis N, Chatterton NJ, Harrison PA et al (2001) Structure of fructans in roots and leaf tissues of Lolium perenne. New Phytol 150:83-95. doi:10.1046/j.1469-8137.2001. 00069.x

Pfeffer PE, Douds DD, Bécard G et al (1999) Carbon uptake and the metabolism and transport of lipids in an arbuscular mycorrhiza. Plant Physiol 120:587-598. doi: 10.1104/pp.120.2.587

Pfeffer PE, Bago B, Shachar-Hill Y (2001) Exploring mycorrhizal function with NMR spectroscopy. New Phytol 150:543-553. doi:10.1046/j.1469-8137.2001.00139.x

Pollock CJ, Jones T (1979) Seasonal patterns of fructan metabolism in forage grasses. New Phytol 83:9-15. doi: 10.1111/j.1469-8137.1979.tb00720.x

Rasmussen S, Parsons AJ, Bassett S et al (2007) High nitrogen supply and carbohydrate content reduce fungal endophyte and alkaloid concentration in Lolium perenne. New Phytol 173:787-797. doi:10.1111/j.1469-8137.2006.01960.x

Rasmussen S, Parsons AJ, Popay A et al (2008a) Plant-endophyte herbivore interactions: more than just alkaloids? Plant Signal Behav 3:1-4

Rasmussen S, Parsons AJ, Xue H et al (2008b) Metabolic profiles of Lolium perenne are differentially affected by nitrogen supply, carbohydrate content, and fungal endophyte infection. Plant Physiol 146:1440-1453. doi: 10.1104/pp.107.111898

Richardson MD, Chapman GW Jr, Hoveland CS et al (1992) Sugar alcohols in endophyte-infected tall fescue under drought. Crop Sci 32:1060-1061

Rowan DD (1993) Lolitrems, peramine and paxilline: mycotoxins of the ryegrass/endophyte interaction. Agric Ecosyst Environ 44:103-122. doi:10.1016/0167-8809(93) 90041-M

Rowan DD, Latch GCM (1994) Utilization of endophyteinfected perennial ryegrasses for increased insect resistance. In: Bacon CW, White JF Jr (eds) Biotechnology of endophytic fungi in grasses. CRC Press, Boca Raton

Rowan DD, Hunt MB, Gaynor DL (1986) Peramine, a novel insect feeding deterrent from ryegrass infected with the endophyte Acremonium loliae. J Chem Soc Chem Commun 1986:935-936. doi:10.1039/c39860000935 
Saikia S, Nicholson MJ, Young C (2008) The genetic basis for indole-diterpene chemical diversity in filamentous fungi. Mycol Res 112:184-199. doi:10.1016/j.mycres. 2007.06.015

Saikkonen K, Wäli P, Helander M et al (2004) Evolution of endophyte-plant symbiosis. Trends Plant Sci 9:275-280. doi:10.1016/j.tplants.2004.04.005

Saikkonen K, Lehtonen P, Helander M et al (2007) Model systems in ecology: dissecting the endophyte-grass literature. Trends Plant Sci 11:428-433. doi:10.1016/j.tplants. 2006.07.001

Salminen SO, Grewal PS (2002) Does decreased mowing frequency enhance alkaloid production in endophytic tall fescue and perennial ryegrass? J Chem Ecol 28:939-950. doi:10.1023/A:1015201616013

Sarosh BR, Sivaramakrishnan S, Shetty HS (2005) Elicitation of defense related enzymes and resistance by L-methionine in pearl millet against downy mildew disease caused by Sclerospora graminicola. Plant Physiol Biochem 43:808-815. doi:10.1016/j.plaphy.2005.06.009

Schardl CL (2001) Epichloë festucae and related mutualistic symbionts of grasses. Fungal Genet Biol 33:69-82. doi: 10.1006/fgbi.2001.1275

Schardl C, Leuchtmann LA, Spiering MJ (2004) Symbioses of grasses with seedborne fungal endophytes. Annu Rev Plant Biol 55:315-340. doi:10.1146/annurev.arplant.55. 031903.141735

Schardl C, Grossman RB, Nagabhyru P et al (2007) Loline alkaloids: currencies of mutualism. Phytochemistry 68:980-996. doi:10.1016/j.phytochem.2007.01.010

Schliemann W, Ammer C, Strack D (2008) Metabolite profiling of mycorrhizal roots of Medicago truncatula. Phytochemistry 69:112-146. doi:10.1016/j.phytochem.2007.06.032

Seto Y, Takahashi K, Matsuurai H et al (2007) Novel cyclic peptide, epichlicin, from the endophytic fungus, Epichlo $\ddot{e}$ typhina. Biosci Biotechnol Biochem 71:1470-1475. doi: 10.1271/bbb.60700

Shachar-Hill Y, Pfeffer PE, Douds D et al (1995) Partitioning of intermediary carbon metabolism in vesicular-arbuscular mycorrhizal leek. Plant Physiol 108:2979-29995

Siegel MR, Latch GCM, Bush LP et al (1990) Fungal endophyte-infected grasses: alkaloid accumulation and aphid response. J Chem Ecol 16:3301-3315. doi:10.1007/BF00 982100

Singh SB, Bais BS, Singh DR (1972) Effect of different carbon and nitrogen sources on growth and sporulation of Claviceps microcephala (Wallr.) Tul. Mycopathol Mycol Appl 46:373-378. doi:10.1007/BF02052134

Solaiman MDZ, Saito M (1997) Use of sugars by intraradical hyphae of arbuscular mycorrhizal fungi revealed by radiorespirometry. New Phytol 136:533-538. doi:10.1046/ j.1469-8137.1997.00757.x

Spiering MJ, Lane GA, Christensen MJ et al (2005) Distribution of the fungal endophyte Neotyphodium lolii is not a major determinant of the distribution of fungal alkaloids in Lolium perenne plants. Phytochemistry 66:195-202. doi:10.1016/j.phytochem.2004.11.021

Springer JP, Clardy J (1980) Paspaline and paspalicine, two indole-mevalonate metabolites from Claviceps paspali. Tetrahedron Lett 21:231-234. doi:10.1016/S0040-4039 (00)71176-2
Springer JP, Clardy J, Wells JM et al (1975) The structure of paxilline, a tremorgenic metabolite of Penicillium paxilli Bainier. Tetrahedron Lett 30:2531-2534. doi:10.1016/ S0040-4039(00)75170-7

Stewart AV (1986) Effect on the Lolium endophyte of nitrogen applied to perennial ryegrass seed crops. NZ J Exp Agr 14:393-397

Strickland JR, Bailey EM, Abney LK et al (1996) Assessment of the mitogenic potential of the alkaloids produced by endophyte (Acremonium coenophialum)-infected tall fescue (Festuca arundinacea) on bovine vascular smooth muscle in vitro. J Anim Sci 74:1664-1671

Strobel GA, Hess WM (1997) Glucosylation of the peptide leucinostatin A, produced by an endophytic fungus of European yew, may protect the host from leucinostatin toxicity. Chem Biol 4:529-536. doi:10.1016/S1074-5521 (97)90325-2

Stryer L (2000) In Biochemistry, 4th edition, 9th printing, W.H.Freeman and Company, New York, p. 718

Takemoto D, Tanaka A, Scott B (2007) NADPH oxidases in fungi: diverse roles of reactive oxygen species in fungal cellular differentiation. Fungal Genet Biol 44:1065-1076. doi:10.1016/j.fgb.2007.04.011

Tanaka A, Tapper BA, Popay A et al (2005) A symbiosis expressed non-ribosomal peptide synthetase from a mutualistic fungal endophyte of perennial ryegrass confers protection to the symbiotum from insect herbivory. Mol Microbiol 57:1036-1050. doi:10.1111/j.1365-2958. 2005.04747.x

Tanaka A, Christensen MJ, Takemoto D et al (2006) Reactive oxygen species play a role in regulating a fungus-perennial ryegrass mutualistic association. Plant Cell 18:10521066. doi: $10.1105 /$ tpc. 105.039263

Tanaka A, Takemoto D, Hyon G-S et al (2008) NoxA activation by the small GTPase RacA is required to maintain a mutualistic symbiotic association between Epichlö festucae and perennial ryegrass. Mol Microbiol 68:11651178. doi:10.1111/j.1365-2958.2008.06217.x

Tapper BA, Lane GA (2004) Janthitrems found in a Neotyphodium endophyte of perennial ryegrass. In: Kallenbach R, Rosenkranz CJ, Lock TR (eds) 5th International Symposium on Neotyphodium/Grass interactions, Fayetteville

Torres MA, Dangl JL (2005) Functions of the respiratory burst oxidase in biotic interactions, abiotic stress and development. Curr Opin Plant Biol 8:397-403. doi:10.1016/j.pbi. 2005.05.014

Tudzynski P, Correia T, Keller U (2001) Biotechnology and genetics of ergot alkaloids. Appl Microbiol Biotechnol 57:593-605. doi:10.1007/s002530100801

Volpin H, Elkind Y, Okon Y et al (1994) A vesicular arbuscular mycorrhizal fungus (Glomus intraradix) induces a defense response in alfalfa roots. Plant Physiol 104:683689

Wang J, Machado C, Panaccione DG et al (2004) The determinant step in ergot alkaloid biosynthesis by an endophyte of perennial ryegrass. Fungal Genet Biol 41:189198. doi:10.1016/j.fgb.2003.10.002

Wright DP, Read DJ, Scholes JD (1998) Mycorrhizal sink strength influences whole plant carbon balance of Trifolium repens L. Plant Cell Environ 21:881-891. doi: 10.1046/j.1365-3040.1998.00351.x 
Young CA, Bryant MK, Christensen MJ et al (2005) Molecular cloning and genetic analysis of a symbiosis-expressed gene cluster for lolitrem biosynthesis from a mutualistic endophyte of perennial ryegrass. Mol Genet Genomics 274:13-29. doi:10.1007/s00438-005-1130-0
Young CA, Felitti S, Shields K et al (2006) A complex gene cluster for indole-diterpene biosynthesis in the grass endophyte Neotyphodium lolii. Fungal Genet Biol 43:679-693. doi:10.1016/j.fgb.2006.04.004 